\title{
Evaluasi Kualitas Pelaporan Manajemen pada Sistem Epicor Perusahaan Manufaktur Berbasis McCall
}

\author{
Faustina Gunadi ${ }^{1}$, Septian Rheno Widianto ${ }^{2}$ \\ Pasca Sistem Informasi Bisnis, STMIK LIKMI ${ }^{1,2}$ \\ Ir. H. Juanda No. 96, Bandung, 022 - 2502121 1,2 \\ v.tinagunadi@yahoo.com ${ }^{1}, \underline{\text { septian.rheno@yahoo.de }}{ }^{2}$
}

Diterima : 30 April 2020. Disetujui: 31 Mei 2020. Dipublikasikan: 7 Juni 2020

\begin{abstract}
Technology develop very fast every year and became needs for many companies. The most popular system is integration system that can integrated all company data's real time and fulfillment management report. Epicor is an ERP, Epicor provides complete module such as: material management until finance management. Epicor can facilities financial custom report using Business Activity Queries (BAQ). BAQ is module report for user to design management reports, besides default report sometimes management have their own requirement. BAQ value added is easy logical coding with $B A Q$ tools inside Epicor. Epicor give an access to user for upload external data at UDCodes, Epicor provide flexible report for user to compare external data from user to realization recorded data at Epicor. This Epicor module very easy for implementation as long as the user understand their management needs and recognize query link from system field. Epicor is a big data with module analytics refer to flexibility of system, then The Quality of Epicor System tested to user with McCall's Model. user response will describe Epicor system quality based on user experience.
\end{abstract}

Keywords: dashboard; Enterprise Resource Planning; BAQ; Epicor; data management tools

Abstrak-- Penggunaan teknologi pada perusahaan semakin berkembang pesat setiap tahunnya. Salah satu yang sedang berkembang adalah sistem yang bisa mengintegrasikan seluruh data perusahaan dengan cepat dan bisa menghasilkan laporan pendukung sesuai dengan kebutuhan manajemen. Salah satu sistem yang bisa mengakomodir ini adalah Sistem ERP bernama Epicor. Epicor memiliki database management system lengkap mulai dari material management sampai dengan finance management dimana seluruh database terutama keuangan dapat dibuat sesuai dengan kebutuhan manajemen dengan menggunakan Business Activity Queries (BAQ). BAQ sendiri dimiliki Epicor untuk memfasilitasi perusahaan yang membutuhkan custom report diluar report default yang sudah ada pada sistem. Kelebihan dari BAQ adalah penggunaan logika coding dipermudah sesuai dengan tools yang ada pada aplikasi dan BAQ dapat mengakomodiir data diluar sistem dengan menggunakan Data Management Tools yang kemudian diterjemahkan ke dalam UDCodes untuk dikombinasikan dengan data yang ada pada sistem. Epicor merupakan sistem ERP yang membuat user-nya lebih mudah untuk menyesuaikan keinginan report-nya karena bisa di-custom sesuai kebutuhan asalkan mengetahui field apa saja yang mau diambil untuk dipresentasikan pada laporan tim manajemen. Sehingga dapat dikatakan pembuatan Dashboard dengan BAQ dapat mengakomodiir kebutuhan tim manajemen perusahaan. Berdasarkan kebutuhan perusahaan akan sistem informasi ini maka peneliti menelaah Modul BAQ pada ERP dengan menggunakan McCall's Model untuk mengetahui kualitas sistemnya.

Kata kunci: dashboard; Enterprise Resource Planning; BAQ, Epicor; data management tools

\section{PENDAHULUAN}

Berkembangnya teknologi informasi pada masa sekarang ini, membuat para pelaku bisnis mulai melihat teknologi untuk digunakan dalam operasional bisnisnya. Perkembangan teknologi untuk operasional bisnis saat ini didukung dengan adanya sistem Enterprise Resource Planning (ERP). Perkembangan ERP ini disambut antusias oleh para pelaku bisnis dikarenakan ERP dapat mengolah data management yang sudah diinput dan terdata pada data warehouse perusahaan. Perusahaan yang menggunakan ERP umumnya adalah perusahaan yang memiliki skala industri yang besar dan membutuhkan laporan yang cepat untuk mendukung keputusan manajemen [1]. Beberapa program ERP yang banyak digunakan perusahaan besar di Indonesia adalah System Application and Processing (SAP), Enterprise Resource Planning (Epicor). Epicor merupakan sistem ERP dan masih terkategorikan baru di Indonesia, Epicor secara harga lebih terjangkau dari SAP, dan Epicor bisa dimodifikasi oleh pengguna aplikasinya dan interface mudah dipahami. Berdasarkan pengamatan ada website client list Epicor yang semakin bertambah di Indonesia, maka peneliti tertarik untuk mendalami cara Epicor memproses database management untuk menghasilkan output laporan manajemen menggunakan modul Business 
Activity Queries (BAQ) pada Epicor. Perkembangan Epicor di Indonesia menjadi pesaing SAP, dikarenakan Epicor memunculkan pilihan bagi penggunanya untuk membeli modul yang dibutuhkan dan memberikan kemudahan dengan dapat customize berdasarkan kebutuhan user. Akan tetapi, dari segi harga tentunya cukup bersaing. Beberapa perusahaan manufaktur sudah menggunakan ERP untuk menunjang kemudahan pencatatan, monitoring, laporan, evaluasi, dan analisa yang real time. Epicor pun mengutamakan kemudahan bagi user yang bukan berlatar belakang dari Teknologi Informasi untuk memahami cara menggunakan big data Epicor supaya dapat dibuat laporan sesuai kebutuhan dengan menggunakan module BAQ. Kemudahan dari BAQ Epicor ini menarik perhatian peneliti untuk menelaah lebih dalam Epicor BAQ menggunakan Metode McCall's untuk menilai kualitas yang akan diteliti dalam penelitian ini.

Database Management dalam perusahaan perlu dijaga kerahasiannya dikarenakan database tersebut dapat mempresentasikan informasi manajemen untuk mengulas performa bisnis, kondisi finansial perusahaan, peluang inovasi produk, dan sebagainya yang terkait dengan informasi untuk pengembangan perusahaan ke depan. Akan tetapi, data tersebut masih terkumpul dan belum diarahkan kebutuhan analisanya sehingga membutuhkan sistem pengolahan, yakni sistem yang berbasis ERP [2]. Epicor merupakan sistem aplikasi ERP yang cukup fleksibel dikarenakan menyediakan fasilitas bagi user untuk membuat output laporan berdasarkan kebutuhan. Selain itu, Epicor memfasilitasi logika coding yang memudahkan user untuk menggabungkan field yang menggunakan deskripsi bisnis dan sederhana pemprograman yang tepat akan membuat dashboard laporan yang dibutuhkan oleh user. Database management yang dimaksud disini adalah penggunanan untuk Analisa data menggunakan sistem ERP. user perlu memahami field dan menguasai upload data dari eksternal data kedalam Epicor dengan menggunakan Data Management Tools (DMT) yang tersedia pada Epicor. DMT merupakan template dari Epicor dengan format excel mewakili field isian yang harus diisi sesuai dengan urutan query dan format cell yang harus diisikan oleh user. Template DMT ini merupakan template dari sistem Epicor yang dapat diisikan data yang user miliki diluar sistem untuk kemudian diupload dengan metode paste insert ke dalam sistem Epicor. user mudah aplikasikan metode paste insert data yang dimiliki karena format excel terintegrasi ke dalam sistem Epicor dengan cepat dan pemahaman pengguna cukup cepat karena format excel.
Beberapa perusahaan besar yang sudah menggunakan ERP khususnya manufaktur dapat terbantu dengan baik dalam operasionalnya. Dikarenakan ERP akan mengkaitkan data produksi dengan data kebutuhan bahan baku, sehingga kemudahan proses pembentukan kebutuhan material produksi cepat. ERP merupakan aplikasi yang diciptakan untuk mengintegrasikan keseluruhan proses bisnis perusahaan dari produksi akan membuat: material resource planning, kemudian terkoneksikan dengan purchase order, setelah barang datang dilakukan goods received note. Tagihan dari supplier masuk ke akunting perusahana untuk kemudian diproses pembayaran dengan invoicing pada sistem yang digunakan kemudian realisasi bayar. Serangkaian proses ini akan tercatat dalam sistem dan membentuk laporan keuangan. Laporan keuangan merupakan dasar utama seluruh shareholder untuk evaluasi dan analisa perkembangan strategi perusahaan ke depan. ERP pun memiliki kelebihan karena bisa diaplikasikan dengan adds on. Kebutuhan teknologi untuk perusahaan setiap tahunnya terus bertambah dikarenakan dengan adanya sistem tidak perlu mengelola orang yang banyak, semua data tersentral, proses terintegrasi karena sudah menggunakan sistem yang saling terhubung antara modul di dalamnya [3].

Oleh karena itu, untuk menguji kualitas dari modul BAQ pada sistem ERP Epicor dilakukan evaluasi kualitasnya menggunakan dua faktor dari sebelas faktor McCall, dua faktor tersebut adalah correctness dan usability dua faktor ini diambil dikarenakan merupakan faktor yang dinilai lebih objektif dibandingkan sembilan faktor lainnya. Kedua faktor kualitas yang diteliti ini menggambarkan kelengkapan dari modul yang tersedia dan digunakan oleh user; sedangkan kegunaan Epicor dari user ini menunjukan kehandalan dari Epicor ini untuk memberikan hasil laporan sesuai dengan kebutuhan user. Melihat Epicor merupakan aplikasi yang dikembangkan oleh perusahaan diluar Indonesia. Oleh karena itu, user khususnya di Indonesia perlu ditelaah respon terhadap sistem aplikasi yang digunakan ini. Penyebab penelitian dari kualitas ini adalah Sistem Epicor ini dapat mengadopsi segala macam regulasi pemerintah Indonesia yang harus dijalankan oleh perusahaan, kemudian berkenaan dengan pihak eksternal yang terlibat seperti supplier dan customer. Pihak eksternal yang memiliki ikatan kerja sama oleh perusahaan terutama di Indonesia tidak semuanya menggunakan teknologi untuk pencatatan dan laporan dalam perusahaannya. Oleh karena itu, besar kemungkinan saat suatu manufaktur sudah besar tetapi pihak eksternal masih belum sistemasi, mengakibatkan manufaktur tersebut cukup kesulitan karena harus ada 
pengaturan atau standard operating procedure yang dilakukan di luar sistem Selain itu, pemilihan McCall dikarenakan McCall adalah merupakan teori pengukuran kualitas yang paling sering digunakan dan komprehensif. Hasil dari testing kualitas ini adalah kesimpulan mengenai keadaan BAQ Epicor saat ini dibandingkan dengan harapan penggunanya dan digunakan sebagai pertimbangan BAQ Epicor masa yang akan datang. Penilaian kualitas McCall's yang diambil untuk diteliti merupakan faktor yang paling sering dianalisa oleh user dikarenakan saat user akan membuat laporan (dashboard). user akan terlebih dahulu mengingat field isian pada kelengkapan modul sistem yang tersedia dan digunakan oleh $u s e r$, kemudian melihat kegunaan dari setiap modul untuk diintegrasikan guna menciptakan laporan bagi pihak terkait dalam perusahaan. Kedua faktor ini menurut peneliti sudah mewakili pengukuran kehandalan Epicor dari penggunanya. Selain itu, mengingat Epicor fleksibel dan dapat di customize sesuai regulasi yang berlaku, maka Epicor yang diimplementasikan di Indonesia dapat memperoleh masukan dari penggunaan untuk dikembangkan kesesuaiannya dengan implementasi yang ada di Indonesia, sehingga Epicor memiliki keunggulan tambahan dan dicari oleh banyak pengguna lainnya.

Database Management (DBMS) adalah desain software untuk mengelola dan optimalkan kapasitas penyimpanan data yang sudah didata dengan sistem dan dapat memenuhi kebutuhan sesuai dengan perkembangan usaha penggunanya. DBMS mencakup area untuk: Database Design, Data Analysis, Concurrency \& Robustness, Efficiency \& Scalability. Penggunaan database management untuk bisnis memberikan banyak keuntungan, dimana pengelolaan database management yang baik bisa menghasilkan [4]:

1. akses dapat dimonitor dan dibatasi sekuritasnya

2. dengan metode tersentral maka data tidak tersebar dimana - mana

3. tempat menyimpan database dapat diback up untuk cadangan jika terjadi hal yang tidak diinginkan

4. administrasi untuk mengelola dokumen dapat ditekan karena sudah disentralisasi dan penunjukan orang yang kontrol jelas

5. database management mengelola keseluruhan data management yang saling terkorelasi dimana relasi antar datanya dapat menghasilkan sejumlah informasi yang dibutuhkan sesuai requirement dari user.

Data disimpan di dalam server yang dapat diakses untuk kepentingan tertentu. DBMS dapat membantu pengelolaan data perusahaan yang besar. Selain itu, karena ada sistem keamanan berdasarkan sekuritas sehingga kebutuhan user tidak tertumpuk kebutuhannya karena sudah diatur sesuai dengan kebutuhan. DBMS merupakan perantara antara user dan basis data akan tetapi untuk basis data menggunakan bahasa pemprograman yang sudah ditentukan oleh perusahaan yang membuat sistem DBMS [5]. DBMS pada sistem ERP dapat digambarkan sebagai kumpulan data transaksi yang besar yang tercatat pada sistem aplikasi yang dipakai perusahaan. Epicor merupakan sistem ERP yang mampu mendata dan mengelola data yang terkumpul untuk laporan bagi manajemen. Database yang digunakan tentu saja berdasarkan logika sistem yang sudah diterapkan oleh user pembuat laporan ke dalam sistem aplikasi, dikarenakan laporan yang tersedia pada ERP hanyalah format laporan default yang secara literatur wajib ada. Akan tetapi, selama perusahaan berjalan pihak manajemen memerlukan analisa yang lengkap terutama bisnis leader. Oleh karena itu, pengguna sistem harus memahami cara evaluasi dan analisa laporan hasil pengolahan big data sistem.

Epicor merupakan salah satu perusahaan penyedia business solution terkemuka di dunia yang didirikan pada tahun 1984, dengan kantor pusat di Irvine, California. Sebelumnya, Epicor dikenal sebagai platinum software yang merancang software akuntansi dengan pasar perusahaan menengah yang disebut Platinum for DOS (PFD) yang kemudian disebut Platinum for Windows (PFW). Saat ini, Epicor memiliki target pasar berupa perusahaan menegah ke atas. Perkembangan Epicor yang cukup pesat di Amerika, membuat Epicor merambah market Asia dikarenakan banyak perusahaan besar bermunculan di Kawasan Asia, seperti: Singapura, Malaysia, Vietnam, Hong Kong, India, Indonesia. Epicor di Indonesia baru dimulai pada tahun 2010. Akan tetapi, minat para pengusaha khususnya di Indonesia untuk sistemasi proses bisnisnya semakin banyak. Beberapa usaha konsultan IT yang bekerja sama dengan Epicor di Indonesia banyak merambah perusahaan manufaktur, dikarenakan pada perusahaan manufaktur ragam proses bisnis banyak dari hulu sampai dengan hilir dan Epicor memiliki semua modul yang diperlukan. Seiring berjalannya waktu, Epicor pun terus berinovasi untuk mengembangkan sistemnya supaya dapat mengakomodir kebutuhan pengguna. Inovasi Epicor mulai dari integrasi adds on seperti dengan aplikasi Doc Stars, untuk meningkatkan proses automasi di pembayaran hutang perusahaan. Inovasi lainnya, yaitu: Epicor Data Analytics = yang menyediakan data analisa standard, Epicor Virtual Assistant $=$ Epicor mengemas AI pada sistemnya dengan tujuan supaya sistem mudah dipahami oleh pengguna, dan inovasi $Q R$ Code untuk memudahkan kontrol Gudang. Penerapan 
teknologi yang terintegrasi dengan Epicor semakin banyak tujuannya untuk mempermudah pelaku bisnis dalam melakukan monitor dan kontrol bisnisnya.

Selain itu, Epicor juga menyediakan solusi lengkap untuk berbagai industri guna meningkatkan efisiensi operasional dan mendorong manfaat kompetitif. Epicor dirancang sebagai solusi hemat biaya serta fleksibel yang menjadi pilihan perusahaan yang ingin mengintegrasikan teknologi internet dan ERP dengan tujuan membuat bisnis global menjadi lebih sederhana. Modul Epicor yang kompetitif dibandingkan dengan ERP lain adalah Business Activity Queries (BAQ). Pada modul ini pengguna aplikasi secara langsung diminta aktif dalam memahami sistem dan memahami setiap field isian yang merupakan query supaya dapat dilogikan ke dalam laporan yang dikehendaki untuk diset dalam tampilan laporan (dashboard) Epicor.

Jurnal Epicor Software Corporation: Epicor Receives New Certifications fromMicrosoft; Epicor Solutions Continue to Leverage Latest Microsoft Technologies for Enhanced Security, Innovative user Interface Features and Performance Enhancements (2009) menyatakan, Epicor Software is a global leader delivering business software solutions to the manufacturing, distribution, retail, hospitality and services industries. Epicor provides integrated enterprise resource planning (ERP), customer relationship management (CRM), supply chain management (SCM) and enterprise retail software solutions that enable companies to drive increased efficiency and improve profitability. Founded in 1984, Epicor celebrates delivering business solutions that provide the scalability and flexibility businesses need to build competitive advantage. The Company's worldwide headquarters are located in Irvine, California with offices and affiliates around the world.

Modul yang selalu ada pada sistem ERP dan ada pada Epicor adalah modul material management $=$ yang berfungsi sebagai modul untuk schedule pemesanan barang, inventory management = yang berfungsi untuk mengontrol ketersediaan barang di Gudang, service management = yang berfungsi untuk merecord service atas aset perusahaan, modul asset management = yang berfungsi untuk mendata, mendepresiasi, dan stock opname aset perusahaaan, modul finance management $=$ modul ini penting karena digunakan oleh semua unit kerja terkait dalam perusahaan yang digunakan untuk merecord semua transaksi masuk dan keluar terkait aliran dana perusahaan. Selain itu, Epicor harus dilakukan setting sesuai dengan kebutuhan perusahaan mulai dari metode pencatatan sampai chart of account yang digunakan perusahaan karena akan menghasilkan laporan keuangan perusahaan yang dibutuhkan oleh manajemen guna pelaporan kepada pihak regulator.

Epicor merupakan aplikasi yang memiliki sistemasi proses bisnis khususnya untuk perusahaan manufaktur. Pengaplikasian Epicor Purchase Request supaya single sistem dan mengurangi proses manual [6]. Penggunaan sistem Epicor pada penelitian ini untuk transisi proses manual yang dikerjakan oleh orang banyak bertransisi menggunakan sistem dan semua proses pemesanan menjadi tersentralisasi dengan baik karena pihak berkepentingan sudah mendapatkan alur informasi sesuai dengan modul yang tersedia pada sistem Epicor. Salah satu yang menjadi keunggulan ERP adalah memfasilitasi Supply Chain Management (SCM) perusahaan berskala besar.

Dalam jurnal yang berjudul: Manajemen basis data MySQL pada Situs FTP Lapan Bandung menjabarkan dimana mySQL digunakan untuk mengelola dan memanggil kueri yang saling terhubung, sehingga dapat mempresentasikan data informasi yang update sesuai dengan kebutuhan informasi dapat di-update, dihapus, ditambahkan oleh penggunanya [7]. Aplikasi Epicor menggunakan logika pengkodean yang sama dengan mySQL tetapi dipresentasikan dengan sederhana oleh aplikasi Epicor.

ERP merupakan aplikasi yang dapat menunjang efektifitas proses diperusahaan. Akan tetapi, ERP bukan aplikasi yang mudah digunakan (not user friendly) harus dioperasikan oleh user yang bersedia mempelajari dan mengerti proses bisnis keseluruhan, dikarenakan keberhasilan suatu sistem dikategorikan ke dalam 3, yaitu kualitas sistem, kualitas informasi, kualitas service. Selain itu, keberhasilan ERP perlu didukung perubahan dari perusahaan yang akan menerapkannya [8].

Software Quality adalah standar untuk menyatakan sebuah software dapat dinyatakan memiliki kualitas sistem yang baik atau tidak baik [9]. Sebuah software yang memiliki kualitas sistem yang baik seharusnya menjalani sejumlah tahapan pada saat perencanaan, perancangan, pengetesan, dan dilakukan SQA terlebih dahulu sebelum akhirnya di publikasikan kepada pengguna [10]. Sistem yang teruji tentunya mengalami tahapan SQA sebelum sistem tersebut dirilis kepada konsumen. Suatu sistem ERP adalah suatu sistem besar karena integrasi semua proses. Hal ini tentunya dilakukan oleh pengembang dari Epicor, perkembangan aplikasinya dari tahun 1984 sampai dengan saat ini. Selain itu, pengintegrasian dengan berbagai teknologi sebagai bukti pemuktahiran sistem aplikasi Epicor.

Kualitas model McCall's merupakan model dasar yang dapat menilai perangkat lunak dengan pembagian faktor kualitas [11]: 
TABEL I. KUALITAS MODEL MCCALL'S

\begin{tabular}{ll}
\hline \multicolumn{1}{c}{ Lingkup } & \multicolumn{1}{c}{ Faktor Kualitas } \\
\hline \multirow{3}{*}{ Correctness } \\
\hline Reliability \\
\cline { 2 - 2 } Usability \\
\hline Efficiency \\
\hline Product Revision & Maintainability \\
\hline Flexibility \\
\hline \multirow{2}{*}{ Product Transition } & Testability \\
\hline & Portability \\
\hline Reusability \\
\cline { 2 - 2 } & Interoperability \\
\hline
\end{tabular}

\section{Correctness}

Sebuah perangkat lunak dianggap benar apabila menghasilkan output yang benar sesuai dengan masukan penggunanya, melakukan proses sistem yang normal dan dapat dibuktikan secara matematis apabila dilakukan validasi atas hasil keluaran. Perangkat lunak pun memiliki tools yang lengkap untuk penggunanya.

\section{Reliability}

Perangkat lunak dapat memenuhi kebutuhan pengguna secara real time, walaupun pada perangkat lunak biasanya ada saja yang menyebabkan kegagalan atau error akan tetapi dalam intensi yang masih bisa diterima penggunanya, dikarenakan kebutuhan pengguna tetap masih bisa terpenuhi.

\section{Usability}

Perangkat lunak mudah untuk dipelajari dan diaplikasikan oleh penggunanya. Kaitan terkait dengan faktor ini adalah: faktor manusia, psikologis, dan ergonomi.

\section{Efficiency}

Perangkat lunak memberikan nilai tambah secara kuantitatif karena penggunaan perangkat lunak membuat proses yang panjang menjadi lebih ringkas dan terarah sesuai dengan pengaturan pengguna.

\section{Integrity}

Perangkat lunak terintegrasi dengan seluruh data yang terecord di dalamnya dan dapat digunakan oleh penggunanya untuk memberikan analisa keseluruhan yang dibutuhkan oleh pengguna.

\section{Maintainability}

Perangkat lunak dapat mengatur dengan baik data yang tersimpan dan keamanan data sesuai dengan setting yang dilakukan oleh pengguna.

\section{Flexibility}

Perangkat lunak mudah menyesuaikan dengan faktor berpengaruh lainnya, sehingga pengguna akan dengan cepat dan mudah untuk menyesuaikan dengan perubahan - perubahan.

\section{Testability}

Perangkat lunak memenuhi kriteria pengujian yang dilakukan kepada perangkat lunak. Hasil tes ini menunjukan kriteria apa saja yang terpenuhi oleh perangkat lunak tersebut dan menunjukan performansi perangkat lunak sesuai kebutuhan penggunanya.

\section{Portability}

Pengukurannya dari segi biaya, perangkat lunak harus ringkas dan mudah dipindahkan oleh penggunanya.

\section{Reusability}

Perangkat lunak apabila sudah tidak digunakan oleh pengguna dapat digunakan kembali untuk keperluan yang lain, sehingga perangkat lunak memiliki nilai guna kembali apabila bisa diintegrasikan dengan aplikasi lainnya.

\section{Interoperability}

Perangkat lunak dapat dipasangkan dengan perangkat lainnya tanpa menunjukan kendala apapun.

Beberapa kualitas sistem dikemukakan oleh beberapa peneliti berikut: Kualitas sistem merupakan totalitas suatu fitur dan karakteristik produk dan jasa bergantung pada kemampuan sistem untuk memuaskan penggunanya [12]. Kualitas sistem merupakan serangkaian konsep sistem yang rumit [13].

Metode analisa data yang digunakan dalam penelitian [14], adalah sebuah set metrik yang digunakan untuk mengukur masing - masing faktor sesuai dengan hubungan pada persamaan (1):

$$
F q=c 1 * m 1+c 2 * m 2+\ldots+c n * m n
$$

$\mathrm{Fq}=$ Faktor software quality

$\mathrm{cl}=$ Bobot yang bergantung pada produk dan kepentingan

$\mathrm{m} 1=$ Metric yang mempengaruhi faktor software quality

\section{METODE PENELITIAN}

Gambar 1 merupakan tahapan metode yang dilakukan peneliti dengan melihat secara dalam fungsi dan kualitas dari BAQ pada Epicor untuk membuat dashboard laporan. 


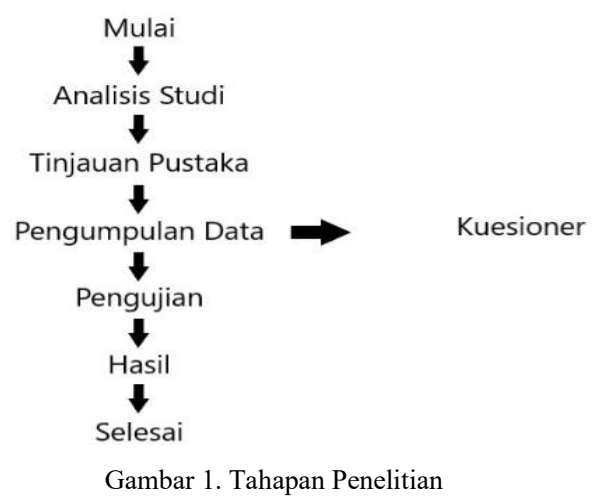

Penjelasan Gambar 1 Tahapan Penelitian :

1. Identifikasi model data yang dapat diinput ke dalam Epicor melalui modul.

2. Identifikasi kemampuan integrasi data diluar dan dalam sistem Epicor pada BAQ.

3. Identifikasi kemudahan pengguna dalam peracangan laporan manajemen pada Epicor dalam bentuk dashboard laporan.

4. Menyebarkan kuesioner untuk menilai kualitas BAQ dari Epicor. Bertujuan untuk mengukur correctness dan usability.

5. Melakukan perbandingan hasil dan teori kualitas McCall untuk membuat analisa dan kesimpulan.

Dalam menelaah BAQ pada Epicor peneliti menelaah fungsi dan proses dalam BAQ tersebut baik untuk DML dan DDL. Selain itu, manajemen perlu mengetahui basic penggunaan BAQ sehingga user paham untuk membaca data dan mengetahui apa yang dimintanya. Oleh karena itu, peneliti menelaah fungsi BAQ - Epicor.

Berikut adalah tahapan yang harus dilakukan dan dicek dalam pembuatan BAQ:

1. Memasukan data ekstern dari luar sistem dalam format excel ke dalam sistem Epicor untuk memonitor realisasi dan anggaran pada tahap Epicor memfasilitasi menggunakan modul: Epicor -> System Maintenance -> user Codes

a. Gambar 2 setelah masuk ke dalam modul user Codes, gunakan sandi untuk menamai file yang berisi data yang mau diupload.

b. Gambar 3 proses upload data eksternal ke dalam Epicor dengan melakukan copy template dari Epicor, kemudian paste ke dalam sistem. Posisikan data yang mau diupload sesuai dengan atribut data sesuai dengan kolom tersedia: Huruf ke kolom character; Angka ke kolom number.

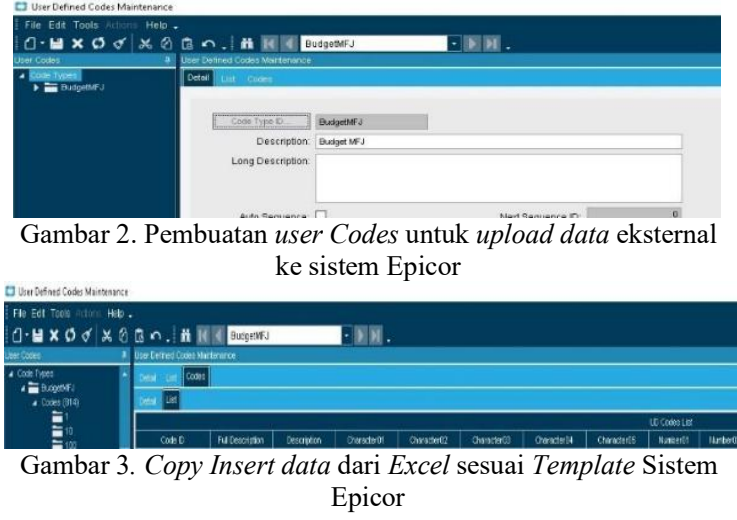

2. Proses mengelola data sistem yang dibutuhkan user dengan pengkodean pada aplikasi Epicor. Modul Epicor yang digunakan untuk pengelolaan data di sistem: Epicor -> Executive Analysis $\rightarrow$ Business Activity Management $\rightarrow$ Setup $\rightarrow$ Business Activity Query.

a. Gambar 4 merupakan pembuatan lembar kerja BAQ sesuai dengan nama yang mudah diingat oleh user yang membuatnya untuk dijadikan kode dashboard yang nantinya akan diupload pada format laporan Epicor.

b. Gambar 5 pembuatan parameter disesuaikan dengan tampilan akan dimunculkan untuk laporan.

c. Gambar 6 dan Gambar 7 proses pembuatan interlink antara setiap query bertujuan untuk menentukan field yang akan ditampilkan. Perlu diingat untuk menampilkan setiap query maka yang harus dilakukan adalah menentukan irisan informasi yang diinginkan menggunakan: LEFT JOIN, RIGHT JOIN, INNERJOIN, kemudian untuk tampilan jangan terlewat untuk posisikan query sebagai Top Level. Tujuan memposisikan Top Level supaya menjadi urutan pertama saat trial output laporan.
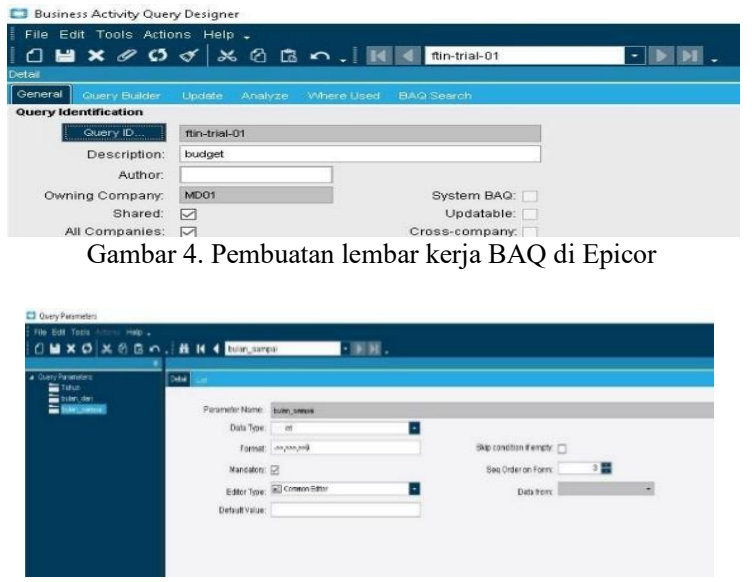

Gambar 5. Pembuatan parameter untuk interface laporan di Epicor 


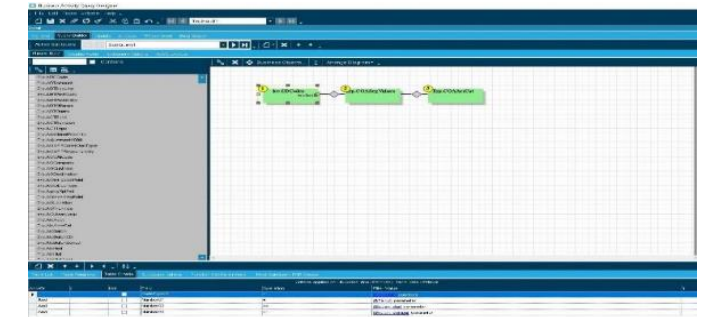

Gambar 6. Query \& Kriteria yang diambil sesuai tampilan yang diinginkan

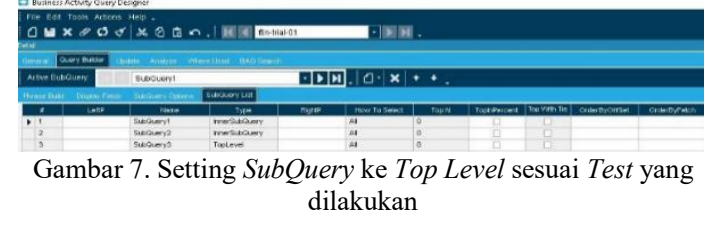

d. Pembuatan setting kriteria. Kriteria disetting dengan dipadupadankan menggunakan parameter yang telah dijabarkan pada poin c.

e. Gambar 8 dan Gambar 9 pembuatan field yang akan ditampilkan dan pengkodean yang akan dimunculkan pada field laporan.

f. Gambar 10 pengecekan Syntax yang dari proses link query yang ada pada sistem Epicor; tahap pengecekan harus dilakukan sebelum interface di-upload ke dalam sistem untuk menjadi laporan default. Pengecekan ini dibuat untuk menginformasikan tampilan dashboard sesuai dengan kebutuhan laporan yang sudah di desain oleh user.

g. Gambar 11 menampilkan dashboard laporan yang sesuai dengan kebutuhan user. Keberhasilan link query harus terjabarkan pada query execution messages tidak boleh ada "error".

h. Gambar 12 merupakan tampilan link query yang sudah diintegrasikan pada BAQ dengan menggunakan tampilan SQL dalam sistem Epicor. Pada gambar ini menjelaskan dimana tidak perlu kompetensi coding IT, user dapat membuat laporan apabila mengetahui query atas modul apa saja yang diambil dan diintegrasikan.
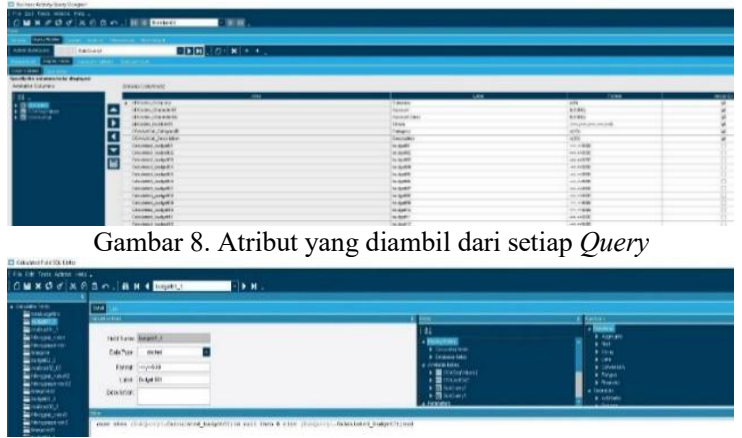

Gambar 9. Setiap atribut yang dibuat menggunakan Coding
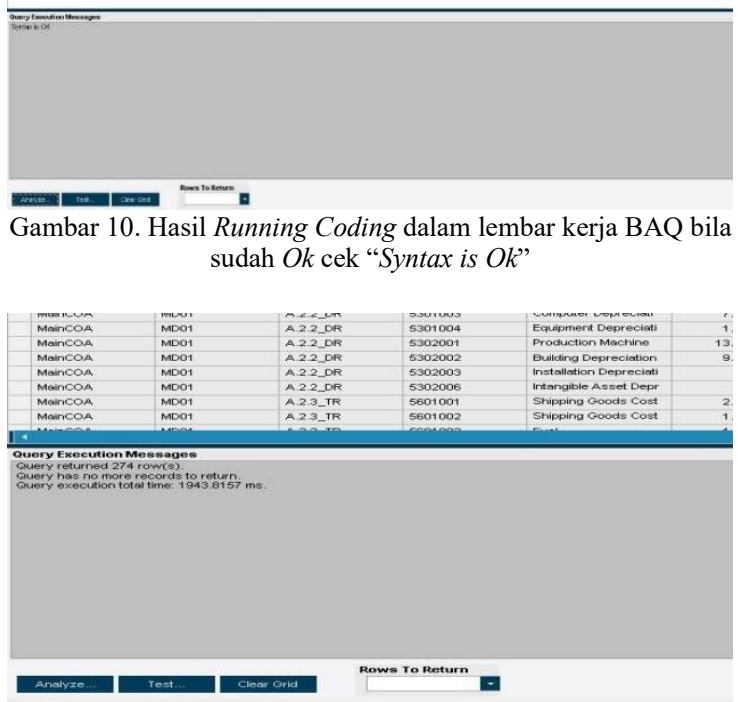

Gambar 11. user Interface sesuai laporan kebutuhan user

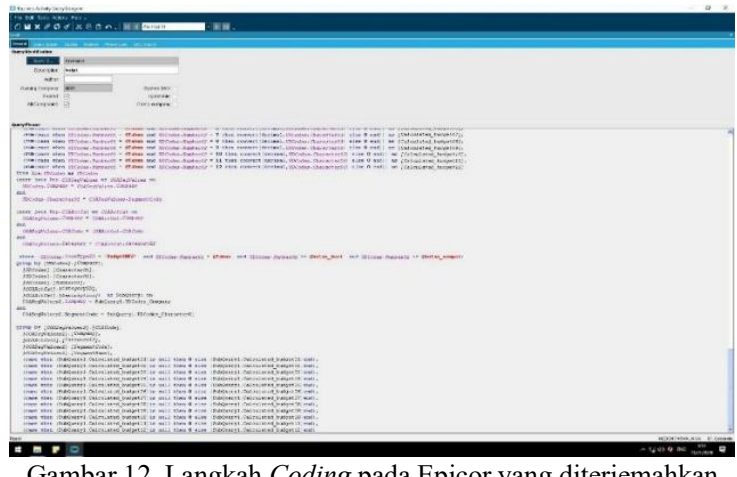

Gambar 12. Langkah Coding pada Epicor yang diterjemahkan sesuai dengan Syntax SQL

Bahasa pemprograman SQL merupakan bahasa yang familiar terlihat penggunaannya di ERP - Epicor dimana setiap waktu tertentu data tersebut akan diolah dan diinfomasikan pengguna. Logika dalam sistem Epicor dimudahkan sehingga setiap user mempelajari interlink field data yang dibutuhkan dalam sistem tanpa harus mengetahui bahasa pemprogram IT yang rumit.

Laporan pada sistem aplikasi Epicor dapat dilakukan oleh user langsung tanpa harus menunggu programmer asalkan paham field yang akan diambil dari sistem dan memahami proses bisnis untuk mendukung dashboard lebih cepat terselesaikan.

Sedangkan secara pengukuran kualitas sistem BAQ dari Epicor ini menggunakan tahapan penilaian kualitas berdasarkan metode McCall [15] :

a. Menentukan kriteria atas setiap faktor McCall's untuk ini yang digunakan oleh peneliti adalah correctness dan usability

b. Menentukan bobot setiap kriteria: Sangat Tidak Penting $=0,1$, Tidak Penting $=0,2$, Penting $=0,3$, Sangat Penting $=0,4$. 
c. Menentukan skala nilai kriteria: Sangat Tidak Setuju $=1$, Tidak Setuju $=2$, Setuju $=$ 3, Sangat Setuju $=4$.

d. Respon dari responden dinilai berdasarkan kriteria hasil

e. Menggunakan perhitungan Indrajit hitung faktor correctness

f. Nilai faktor kualitas diubah menjadi persentase (\%). Nilai maksimal $100 \%$ dan minimum $0 \%$. Dengan kategori sebagai berikut [16]:

1. $81-100 \%=$ Sangat Baik

2. $61-80 \%=$ Baik

3. $41-60 \%=$ Cukup Baik

4. $21-40 \%=$ Tidak Baik

5. $<21 \%=$ Sangat Tidak Baik

\section{HASIL DAN PEMBAHASAN}

Peneliti melakukan analisa lebih lanjut kepada para user yang menggunakan aplikasi Epicor. Epicor secara modul tahapan sistem dijelaskan pada gambar 1 sampai dengan gambar 12 user yang menggunakan Epicor wajib mengikuti tahapan yang sudah dijabarkan. Akan tetapi untuk, perancangan dan output laporan diserahkan kepada user selaku penyedia laporan untuk team manajemen. Untuk menunjang pengukuran kualitas sistem ini peneliti melakukan penilaian kepada user pengguna sebanyak 50 responden dengan hasil analisa yang dijabarkan berikut.

Analisa penelitian untuk penentuan bobot kriteria faktor kualitas menggunakan penilaian judgement dari ahli perusahaan manufaktur tempat peneliti melakukan penelitian untuk BAQ Epicor. Dengan pengajuan kriteria faktor kualitas untuk mengukur correctness dan usability. Menghitung rata - rata nilai yang didapatkan dari hasil responden yang terkumpul sebanyak 50 orang responden, kemudian dihitung nilai Kualitas faktornya kemudian hasil perhitungan responden tersebut dijumlahkan dan dibagi dengan total nilai faktor kualitas. Berikut adalah hasil pengukuran faktor correctness dan usability dari BAQ Epicor:

TABEL II. HASIL PENILAIAN FAKTOR KUALITAS

\begin{tabular}{|c|c|c|c|c|c|}
\hline \multicolumn{6}{|c|}{ CORRECTNESS } \\
\hline Faktor & \multicolumn{2}{|c|}{ Kriteria } & Nilai & Bobot & Rata \\
\hline \multirow{11}{*}{$\begin{array}{l}\text { Correctn } \\
\text { ess }\end{array}$} & \multirow{11}{*}{$\begin{array}{l}\text { Compl } \\
\text { eteness } \\
\text { (keleng } \\
\text { kapan) }\end{array}$} & Epicor & 1456 & 04 & 3.64 \\
\hline & & BAQ & & & \\
\hline & & mampu & & & \\
\hline & & menampilk & & & \\
\hline & & $\begin{array}{l}\text { an } \\
\text { informasi }\end{array}$ & & & \\
\hline & & pada setiap & & & \\
\hline & & menu yang & & & \\
\hline & & disediakan & & & \\
\hline & & Epicor & 1,4 & 0,4 & 3,5 \\
\hline & & BAQ & & & \\
\hline & & mampu & & & \\
\hline
\end{tabular}

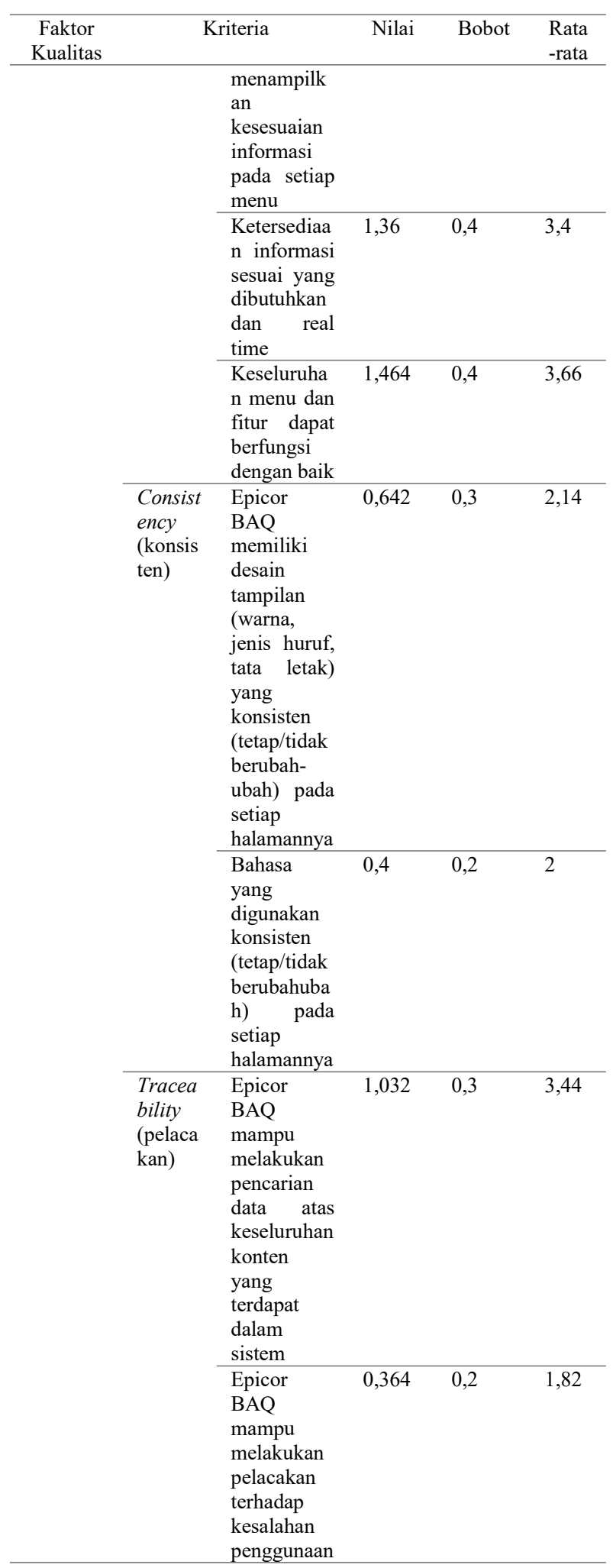

Berdasarkan TABEL II didapatkan perhitungan Correctness:

$0,4(1,456)+0,4(1,4)+0,4(1,36)+0,4(1,464)+$ $0,3(0,642)+0,2(0,4)+0,3(1,032)+0,2(0,364)$ menghasilkan nilai Correctness $=8,118$ persentase yang didapat $=8,118 / 10,4=78,06 \%$ 
Berdasarkan kategori pada TABEL II diambil kesimpulan faktor kualitas correctness untuk aplikasi BAQ Epicor memiliki interpretasi "Baik" sesuai dengan pengkategorian Arikunto.

Berdasarkan kualitas correctness McCall's pengguna mendapatkan informasi yang dibutuhkan oleh pengguna dari BAQ Epicor. Selain itu, menu dan fitur yang digunakan oleh pengguna mudah untuk diintegrasikan sehingga informasi dapat dijadikan laporan karena terdapat informasi yang lengkap. BAQ Epicor memiliki tampilan yang konsisten karena Bahasa yang digunakan mudah dipahami oleh penggunanya. Selain itu, BAQ Epicor dapat dipasangkan parameter yang diperlukan oleh penggunanya sehingga laporan merupakan hasil evaluasi yang sudah melewati monitoring dan kontrol. Pengguna menilai BAQ Epicor dapat memenuhi kebutuhan penggunanya dengan baik.

\section{TABEL III. HASIL PENILAIAN FAKTOR KUALITAS} USABILITY

\begin{tabular}{|c|c|c|c|c|c|}
\hline $\begin{array}{c}\text { Faktor } \\
\text { Kualitas } \\
\text { Usability }\end{array}$ & \multicolumn{2}{|c|}{ Kriteria } & \multirow{2}{*}{$\begin{array}{l}\text { Nilai } \\
0,744\end{array}$} & \multirow{2}{*}{$\begin{array}{l}\text { Bobot } \\
0,4\end{array}$} & \multirow{2}{*}{$\begin{array}{l}\begin{array}{l}\text { Rata } \\
\text {-rata }\end{array} \\
1,86\end{array}$} \\
\hline Usability & \multirow[t]{4}{*}{$\begin{array}{l}\text { Operability } \\
\text { (kemudahan } \\
\text { mengoperasi } \\
\text { kan } \\
\text { program) }\end{array}$} & $\begin{array}{l}\text { Epicor } \\
\text { BAQ } \\
\text { dapat } \\
\text { dioperasi } \\
\text { kan } \\
\text { dengan } \\
\text { mudah }\end{array}$ & & & \\
\hline & & $\begin{array}{l}\text { Menu } \\
\text { dan } \\
\text { informasi } \\
\text { yang } \\
\text { ditampilk } \\
\text { an dapat } \\
\text { dipahami } \\
\text { dengan } \\
\text { baik }\end{array}$ & 1,04 & 0,4 & 2,6 \\
\hline & & $\begin{array}{l}\text { Informasi } \\
\text { yang } \\
\text { dibutuhk } \\
\text { an dapat } \\
\text { ditemuka } \\
\mathrm{n} \text { dengan } \\
\text { mudah } \\
\text { dan cepat }\end{array}$ & 0,888 & 0,4 & 2,22 \\
\hline & & $\begin{array}{l}\text { Secara } \\
\text { keseluruh } \\
\text { an, } \\
\text { Epicor } \\
\text { BAQ } \\
\text { dapat } \\
\text { memberi } \\
\text { kan } \\
\text { kepuasan } \\
\text { dan } \\
\text { kenyama } \\
\text { nan } \\
\text { terhadap } \\
\text { pengguna }\end{array}$ & 0,912 & 0,4 & 2,28 \\
\hline & $\begin{array}{l}\text { Training } \\
\text { (sejauh } \\
\text { mana } \\
\text { Epicor BAQ } \\
\text { membantu }\end{array}$ & $\begin{array}{l}\text { Ketersedi } \\
\text { aan menu } \\
\text { berupa } \\
\text { petunjuk } \\
/ \text { bantuan }\end{array}$ & 0,68 & 0,2 & 3,4 \\
\hline
\end{tabular}

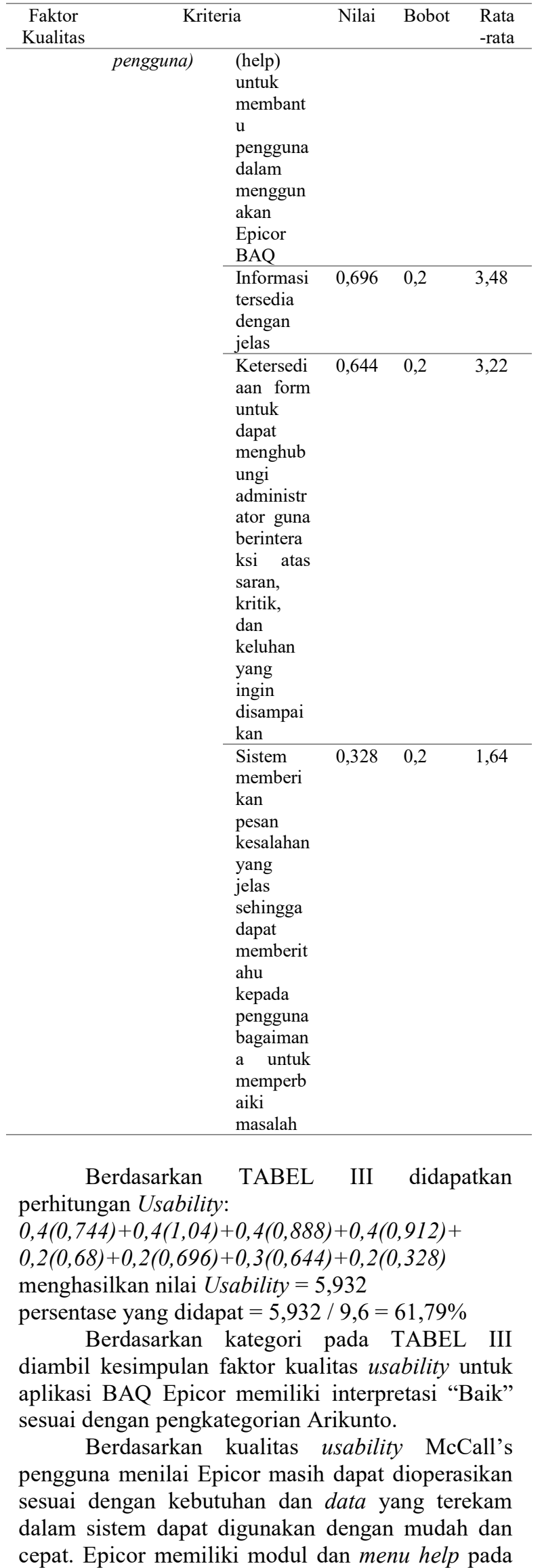


sistem, sehingga pengguna dapat real time membaca help yang sudah ada pada sistem. Selain itu, Epicor memberikan warning jika ada proses yang tidak sesuai atau ada kekurangan menginput informasi pada sistem. Epicor dapat menjalankan fungsi validasinya dengan baik, sehingga pengguna tidak terlewat menginput informasi yang dibutuhkan. Pengguna menilai Epicor BAQ ini berguna dalam aktivitas penggunanya terutama untuk perusahaan manufaktur karena dapat mengintegrasikan data dari produksi dan non produksi untuk kebutuhan analisa dan evaluasi laporan.

\section{KESIMPULAN DAN SARAN}

Berdasarkan hasil pengamatan sistem aplikasi ERP, yakni Epicor. Epicor sangat fleksibel karena laporan dapat disesuaikan kebutuhan user, selama user mengetahui proses bisnis dan field yang bisa diambil. Kemudahan lain Epicor dapat melakukan upload data diluar sistem, fungsi DML ada pada Epicor, kemudian untuk pengambilan data sistem DDL dipermudah dengan adanya BAQ, secara proses logika perancangan dashboard sederhana karena mudah diaplikasikan bagi user yang mengetahui proses bisnis dan paham sistem. BAQ dapat dioperasikan pengguna yang tidak memiliki pengetahuan teknologi informasi karena kemudahan menglogikan dari transaksi yang rutin terjadi, yang diperlukan user adalah memahami proses bisnis dan keterkaitan antar modul yang dipakai, sehingga menghasilkan laporan manajemen yang sesuai dengan harapan strategis manajemen. Epicor mampu melakukan analisa untuk skala data yang besar atau dikenal dengan big data, dikarenakan Epicor adalah sistem ERP yang mengintegrasikan data yang diinput oleh keseluruhan user di seluruh unit kerja dalam perusahaan.

Selain itu, Epicor dapat mempresentasikan laporan yang cepat apabila Dashboard diterapkan untuk menggantikan laporan manual, penggantian laporan yang tersistem ini mendukung laporan yang real time, kemudian manajemen dapat mengakses sewaktu diperlukan dengan melihat detail transaksi yang terjadi. Keuntungan bagi perusahaan: paperless, tenaga kerja efektif, waktu tepat, identifikasi cepat, lebih transparan untuk data laporan, user memahami prosesnya, dapat menjadi Best Practice bagi perusahaan lain. Edukasi perancangan BAQ di Epicor dapat dipertimbangkan user untuk mengoptimalkan penggunaan modul pada BAQ-Epicor untuk pelaporan, pelaporan menggunakan BAQ ini akan menghasilkan laporan (dashboard) sesuai dengan template kebutuhan manajemen, sehingga manajemen dapat cepat memberikan keputusan yang bersifat strategis dan analisanya dapat dikeluarkan dari output laporan sistem.

Analisa deskriptif berdasarkan hasil pengukuran kualitas faktor correctness dan usability pada McCall disimpulkan kualitas BAQ Epicor "Baik". Dengan demikian, pengguna yang menggunakan BAQ Epicor merasakan kesesuaian dan kemudahan sistem untuk diaplikasikan dan mendukung untuk menghasilkan laporan pengguna. Akan tetapi, responden yang diambil hanyalah beberapa orang dalam satu divisi untuk penelitian ke depan dibutuhkan sampel responden secara menyeluruh sehingga hasil dapat mendukung perkembangan BAQ Epicor ke depan. Saran untuk pengembangan penelitian ke depan dengan menganalisa faktor kualitas McCall secara menyeluruh terhadap BAQ Epicor sehingga dapat diprediksi faktor kualitasnya secara lengkap, kemudian memunculkan secara lengkap modul sistem Epicor yang bisa dikembangkan berdasarkan hasil penilaian kualitas sistem tersebut, dikarenakan Epicor yang lebih disempurnakan akan memberikan nilai tambah bagi para penggunanya di seluruh negara, karena fleksibilitas Epicor dapat mengakomodiir kebutuhan seluruh user yang menggunakannya.

\section{REFERENSI}

[1] D. Pratama, W. Witjaksono, and N. Ambarsari, "Penerapan Sistem Informasi Berbasis Enterprise Resource Planning Menggunakan SAP Modul Plant Maintenance di PT. Len Industri," Sisfo, 2016, doi: 10.24089/j.sisfo. 2016.09 .003 .

[2] A. Susanto, "Implementasi Sistem Erp (Enterprise Resources Planning) Pt Pos Indonesia: Sebuah Inisiasi Dan Strategi," J. PPI Kominfo, 2013.

[3] F. Nadziroh, "ANALISA PROSES BISNIS SISTEM ERP (ENTERPRISE RESOURCE PLANNING) PADA PERUSAHAAN DISTRIBUTOR BATU BARA," $J$ Teknol. dan Terap. Bisnis, vol. 2, no. 1, pp. 59-64, Mar. 2019, doi: 10.0301/jttb.v2i1.62.

[4] R. Ramakrishnan and J. Gehrke, "Database Management Systems solution," Database Manag. Syst. Solut. Man. Third Ed., 2003, doi: 10.1300/J115v06n04 07.

[5] A. ZAKIA, "PENERARAPAN SISTEM INFORMASI MANAJEMEN PENDIDIKAN UNTUK PENGELOLAAN DATA DI SMPN 1 TALAMAU," $J$. Chem. Inf. Model., 2013, doi: 10.1017/CBO9781107415324.004.

[6] E. (Ely) Kartikaningdyah and A. (Agustina) Agustina, "Purchase Request Through Epicor System in Manufacturing Company," J. Appl. Account. Tax., vol. 1, no. 1, pp. 32-36, 2016, doi: 10.5281/ZENODO.1307268.

[7] A. Saputra, "Manajemen basis data Mysql Pada Situs FTP Lapan Bandung," Ber. Dirgant., 2012.

[8] R. E. Putra, "Pengaruh Critical Success Dalam Implementasi Enterprise Resource Planning (ERP) Terhadap Kinerja Perusahaan Studi Pada PT. Angkasa Pura II (Persero)," Akuntabilitas J. Ilmu Akuntansi, Vol. 11 (2), 2018381 - 394. P-ISSN 1979-858X; E-ISSN 2461 1190. DOI 10.15408/akt.v11i2, 2018, doi: 10.15408/akt.v11i2.8792.

[9] R. Fitzpatrick, Quantum mechanics. 2015.

[10] D. Galin, Software quality assurance: from theory to 
implementation. 2004.

[11] J. a. McCall, P. K. Richards, and G. F. Walters, "Factors in Software Quality," at'l Tech. Inf. Serv., 1977.

[12] P. Kotler, "Marketing management/Philip Kotler, Kevin Lane Keller," Pearson Educ. Int., 2012.

[13] R. S. Pressman, Software Engineering: A Practitioner's Approach, Seventh Edition. 2010.

[14] R. E. Indrajit, "Kriteria Penjamin Kualitas Software," no. 21 Januari 2016, 2016.

[15] O'Brien; James A. and George M. Marakas; penerjemah; Liza Nurbani Puspitasari dan Hirson Kurnia, "Sistem informasi manajemen," 2014.

[16] Tumarni, "Pengaruh Kualitas Sistem, Kualitas Informasi dan Penggunaan Nyata erhadap Kepuasan Pemakai Laporan keuangan (Studi Pada Satuan kerja Perangkat Daerah Pemerintah Provinsi Jambi)," J. Chem. Inf. Model., 2015, doi: 10.1017/CBO9781107415324.004. 